\title{
Advertisement calls of Bolivian species of Scinax (Amphibia, Anura, Hylidae)
}

\author{
Ignacio de la Riva, Rafael Márquez \& Jaime Bosch \\ Departamento de Biología Evolutiva, Museo Nacional de Ciencias Naturales, 28006 Madrid, Spain
}

Keywords: Anura, Hylidae, Scinax, Bolivia, advertisement calls, ecology, phylogeny

\begin{abstract}
The advertisement calls of eight Bolivian species of Scinax are described including information on the calling behaviour of each species. A characteristic audiospectrogram and oscillogram are presented for each species, as well as numerical information about the spectral and temporal features of the calls. Two phenograms based on the characteristics of the mating calls are constructed, the first one using a traditional multivariate technique (UPGMA) and the second one using audiospectrogram correlation, a new technique that allows holistic comparisons of single vocalizations.
\end{abstract}

\section{Resumen}

Se describen las llamadas de apareamiento de ocho especies de Scinax de Bolivia, aportando información sobre su comportamiento fonador. Un audiospectrograma y un oscilograma son presentados para cada especie junto con información numérica sobre las características temporales y espectrales de las vocalizaciones. Se presentan dos fenogramas basados en las características de las llamadas, uno de ellos usando metodología multivariante tradicional (UPGMA), y el segundo usando una novedosa metodología basada en la correlación de los archivos de imagen de los audioespectrogramas.

\section{Introduction}

The Neotropics contain by far the most diverse anuran fauna in the world, and a great number of species is being described each year. Central and South America are the subject of a number of exploratory studies that provide an ever more complex view of the richness in anuran diversity (see Donnelly \&
Myers, 1991; Duellman \& Salas, 1991). Among the South American countries, Bolivia contains some of the least known areas, and its anuran fauna has been the subject of several recent discoveries (De la Riva, 1990a, 1990b, 1992a, 1992b, 1993; Reynolds \& Foster, 1992).

In this study we contribute to the knowledge of Bolivian herpetofauna by presenting the characteristics of the advertisement calls of eight species in the hylid genus Scinax, previously known as Ololygon (see Duellman \& Wiens, 1992). The advertisement calls of two of these species are described for the first time.

The genus Scinax was known for many years as Ololygon Fitzinger, 1843. Ololygon was resurrected from the synonymy of Hyla by Fouquette \& Delahoussage (1977), based on sperm characters. Although the validity of this feature was questioned by some authors, some characteristic morphological features are shared by all the species in this genus. Recently the correct nomenclature for the genus was considered to be Scinax (see Duellman \& Wiens, 1992). Among other morphological features, this genus differs from Hyla mainly by lacking a membrane between toes I and II or having only a vestigial fringe along the inner margin of the second toe. Additionally, they have truncate disks, which are wider than long, on the hands (Duellman \& Wiens, 1992).

The genus Scinax is one of the most abundant and conspicuous groups of frogs in the Neotropics. Frost (1985) reports 54 species in the genus (as Ololygon) and several more have been described 
since then. De la Riva (1990) lists eight species present in Bolivia, although two additional species have been described since then (De la Riva, 1990b, 1993). The genus has been divided into several phenetic groups. The eight species considered in the present study belong to at least three (possibly four) different species groups. The first group is the $S$. rubra group that includes $S$. rubra, as well as probably $S$. chiquitana, $S$. fuscovaria, and $S$. nasica. The second group is the $S$. rostrata group, that would include $S$. garbei and $S$. nebulosa. The third group is the $S$. staufferi group which includes $S$. parkeri and possibly $S$. nasica. The fourth potential group is the $S$. $x$-signata group to which $S$. nasica has been assigned according to some authors. Of these four groups only the $S$. rostrata group appears to have solid phylogenetic consistency (see Duellman \& Wiens, 1992, for further details on the taxonomy of the group). These four groups include all eight species considered in the present study except for $S$. castroviejoi, which has not been assigned to any group (De la Riva, 1993).

Since the inception of sound analysis techniques, anuran mating calls have been considered to be important taxonomic determinants due to their role as pre-zygotic species isolating mechanisms (Blair, 1955, 1958, 1959; Jameson, 1955; Johnson, 1959). The richness of the anuran tropical fauna allows for comparative studies of the vocalisations, either from ecological (Hödl, 1977; Drewry \& Rand, 1983; Zimmerman, 1983) or from taxonomic standpoints (Barrio, 1965, 1966).

In general terms, it is accepted that the mating calls of anurans do not show homologies above the genus level, but some similarities among calls that may have phylogenetic significance at generic and infrageneric level may be expected. The validity of vocalisations in phylogenetic studies is, however, limited and depends on the group of anurans considered. According to Schiøtz (1973:313) "the voice follows the taxonomy to a certain extent, which is quite natural as the voice is a product of the morphology of the species." However, convergences are often found between species of different families and acoustic partitioning in allopatric anuran communities seems to have similar characteristics (Duellman \& Pyles, 1983).
In the present paper, the calls of eight species of Scinax from Bolivia are compared with previously published descriptions from other areas of South America, to point to possible inconsistencies in taxonomy, or future areas of taxonomic research. Finally, two different methodologies are used to generate phenetic trees of affinities among vocalisations which allow to discuss some relationships of the species within Scinax. The first method is a multivariate technique, and the second method is an innovative technique based on the correlation of audiospectrograms. The relationships resulting from the study of the advertisement calls are compared with the currently accepted species groups.

\section{Material and methods}

Recordings were obtained in Bolivia by the first author from 1987 to 1990 . Unless otherwise specified, calls were recorded in Puerto Almacén, northwestern part of Santa Cruz Department $\left(15^{\circ} 46^{\prime} \mathrm{S} 62^{\circ} 15^{\prime} \mathrm{W}\right)$, an Amazonian locality in wet subtropical forest (Tosi et al., 1975). Recording equipment included either a Sony WM D6C or a Sanyo M1120 tape recorder and a Sennheiser Me 80 directional microphone. A representative audiospectrogram and oscillogram were presented for a 2.5 seconds recording segment for each species. A longer recording (20-60 seconds) was analysed to generate numerical information on the spectral and temporal characteristics of the sounds. For each species, we selected for analysis the calls of a single representative individual which emitted vocalisations which appeared to be "normal" to the human ear. The criteria for the choices were also based on the certainty of the identification of the recorded individual and in the quality of the recording.

Recordings were processed with a Macintosh-based digital signal analysis system. Digitalisation and editing were completed at a sampling frequency of $44.1 \mathrm{kHz}$ and 16 bit resolution with Sound Tools hardware and software. Signalyze software was used to obtain numerical information and to generate audiospectrograms and oscillograms. Frequency information was obtained through fast Fourier transform (FFT, width 1024 points). The terminology used for the description of the advertisement calls follows Heyer et al. (1990).

A total of 12 different call characteristics were compared in a phenetic analysis. The variables considered were: note duration, pulse rate (pulses per second), dominant frequency, fundamental frequency, other frequency with substantial energy, minimum number of notes per call, maximum number of notes per call, number of pulses per note, call repetition rate (calls per minute), note repetition rate (notes per minute within the call), number of different types of notes, and ratio pulse duration/interpulse interval. Variables were linearly transformed in the original matrix in order to standardise the scales of the different variables. The standardised matrix was used to calcu- 
late the "average taxonomic distance" between each species pair (after Sneath \& Sokal, 1973). The resulting unrooted phenetic tree was generated through the application of an unweighted pair-group-method arithmetic average (UPGMA) on the previously calculated matrix (NTSYS statistical package, Rohlf, 1992). The methodology and the parameters used were similar to those used for the comparison of advertisement calls of 18 species of $H y l a$ from Bolivia by Márquez et al. (1993).

In addition to the UPGMA analysis, a second method for quantitatively comparing animal vocalisations was used, based on the comparison of the audiospectrograms of single notes of the advertisement call. This method, described in Clark et al. (1987) allows for a comparison of a full representation of a sound's structure in time and frequency rather than of individual acoustical features. The software used for the correlation process was available in "Canary" (Cornell Lab. of Ornithology, Ithaca, New York). To the best of our knowledge, it is the first time that this method is applied to the quantitative comparison of the vocalisations of different taxa. When the advertisement call was composed of more than one note, the primary note was used for comparisons (we defined the primary note as the note which was never omitted from the call or the loudest note).

Unless otherwise specified, collected individuals were deposited in the Centro de Estudios Tropicales, Sevilla, Spain, and/or in the Museo de Historia Natural "Noel Kempff Mercado", Santa Cruz de la Sierra, Bolivia.

\section{Results and discussion}

\section{Description of the advertisement calls}

The audiospectrograms and oscillograms of a 2.5 second section of the calls of the different species are shown in Figs. 1 and 2. A summary of the numerical information from the sound analyses is shown in Table I. The phenetic trees produced by the UPGMA analyses and by audiospectrogram correlation are shown in Figs. 3 and 4.

Scinax castroviejoi (De la Riva, 1993)

This recently described large species of Scinax (maximum snout-vent length (SVL): males 41.9 $\mathrm{mm}$, single female known $48.7 \mathrm{~mm}$ ) occurs in temperate valleys of the eastern slopes of the Andes from Bolivia to northern Argentina. Calls were recorded in a small lagoon near Bermejo (Dept. of Santa Cruz, Bolivia, $18^{\circ} 97^{\prime} \mathrm{S} 63^{\circ} 38^{\prime} \mathrm{W}$ ). Males migrated to the shore at dusk, and called perched on small bushes or rushes. Scinax castroviejoi is probably a prolonged breeder because it did not rain during the two days when the pond was visited and males were active and calling.
The mating call always consisted of two similar notes emitted together in rapid succession (Fig. 1a). Both were short (26 and 28 milliseconds), with a high number of pulses, low fundamental frequency $(891 \mathrm{~Hz})$, and a relatively high dominant frequency $(2400$ and $2850 \mathrm{~Hz}$ ). For the quantitative comparisons with other calls the second note in the sequence was considered as the primary note because of its greater intensity. De la Riva (1993) described the calls of this species from the same locality and from the same recordings.

\section{Scinax chiquitana (De la Riva, 1990a)}

This medium-sized species (maximum SVL: males $32.0 \mathrm{~mm}$, females $35.3 \mathrm{~mm}$ ) probably belongs to the S. rubra group (De la Riva, 1990b) and occurs in the rain forests of northern Bolivia and southern Peru (Duellman \& Salas, 1991). At Puerto Almacén it was an explosive breeder, forming large aggregations of males during the rainy season. However, mating calls were only heard sporadically.

Males usually called while perched on aquatic plants or bushes emerging from temporal ponds or in their near vicinity. The advertisement call was composed of a single type of note of intermediate duration (243 ms), pulsed, and repeated at regular intervals (Fig. 1b). The mean dominant frequency was of $2172 \mathrm{~Hz}$. No previous records of the vocalisations of this species were available.

\section{Scinax fuscovaria (Lutz, 1925)}

This large species (maximum SVL: males $50.2 \mathrm{~mm}$, females $53.2 \mathrm{~mm}$ ) probably belongs in the $S$. rubra group (Fouquette \& Delahoussaye, 1977; Frost, 1985). It occurs in open and forest habitats throughout the Chaco, Cerrado, and the subtropical forests of Brazil, Argentina, Paraguay, and Bolivia. At Puerto Almacén S. fuscovaria was an explosive breeder forming large choruses in temporal ponds following heavy rains.

Males called from bushes or small trees, usually perching directly on trunks or thick branches. The call was short and consisted of one note with low frequency $(860 \mathrm{~Hz})$ and a low pulse rate $(50$ pulses per second) (Fig. 1c). The call was emitted in fast succession at regular intervals. De la Riva (1993) provided basic parameters of the calls of $S$. fus- 

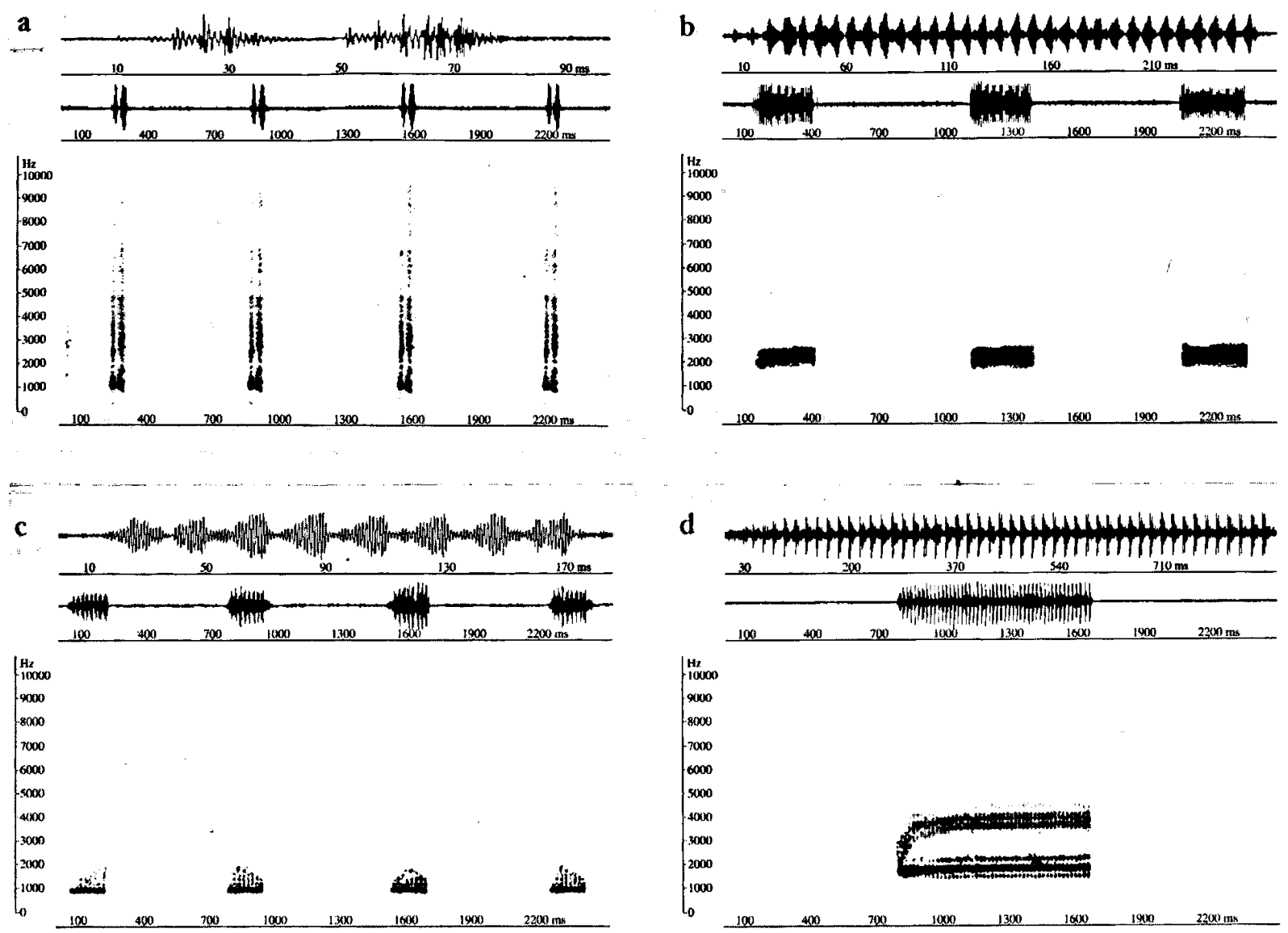

Fig. I. From bottom to top: audiospectrogram and oscillogram of a 2.5 second recording of a characteristic mating call. 'Top: expanded oscillogram showing the temporal details of the notes; a, Scinax castroviejoi; b, Scinax chiquitana, c, Scinax fuscovaria; d, Scinax garbei.

covaria from Puerto Almacén which are coincident with our description.

Scinax garbei (Miranda-Ribeiro, 1926)

This is a medium-sized species (maximum SVL: males $39.8 \mathrm{~mm}$, females $42.1 \mathrm{~mm}$ ) of the $S$. rostrata group (Duellman, 1972). It is widespread in the upper Amazon Basin from Colombia to Bolivia. Apparently, there are marked differences in size between populations (Heyer, 1977). At Puerto Almacén $S$. garbei was a prolonged breeder during the rainy season.

Males called perched head-down on trunks or leaves near the shore of temporal or semi-permanent ponds. The call consisted of one long note $(950$ $\mathrm{ms})$, highly pulsed, with a dominant frequency of
$3715 \mathrm{~Hz}$ and a fundamental frequency of $1695 \mathrm{~Hz}$ (Fig. 1d). The calls were separated by long intervals of variable duration, averaging $1300 \mathrm{~ms}$.

Duellman (1970a, 1972, 1978) described the mating call of Scinax garbei from Santa Cecilia, Ecuador (in 1970a and 1972, Duellman considered the species to be in the genus Garbeana; in 1978, Duellman referred to it as Hyla). He described the call as being a single, moderately long pulsed note, repeated at a rate of 14 notes per minute. The note repetition rate of our recordings is nearly twice that figure, whereas the duration of the note reported for the Ecuadorian frogs (range 160-260 ms) is markedly shorter than the duration found by us (range 295-1469 ms). The pulse rates do not show much agreement either; calls from Ecuador had 
a
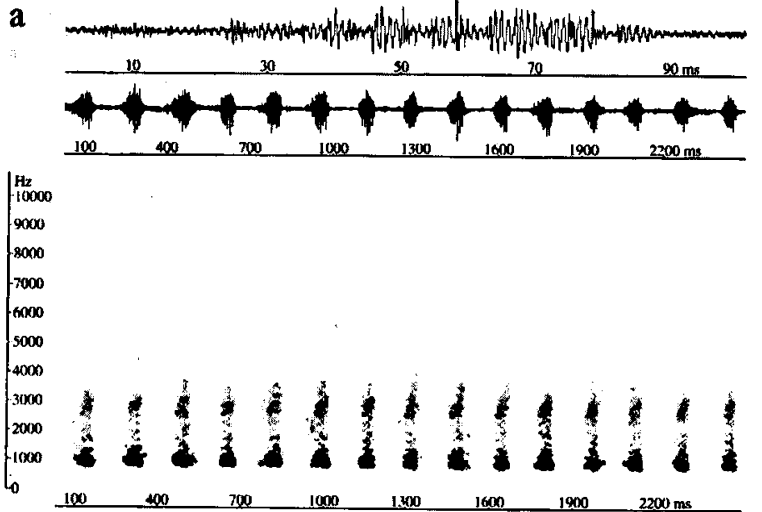

c
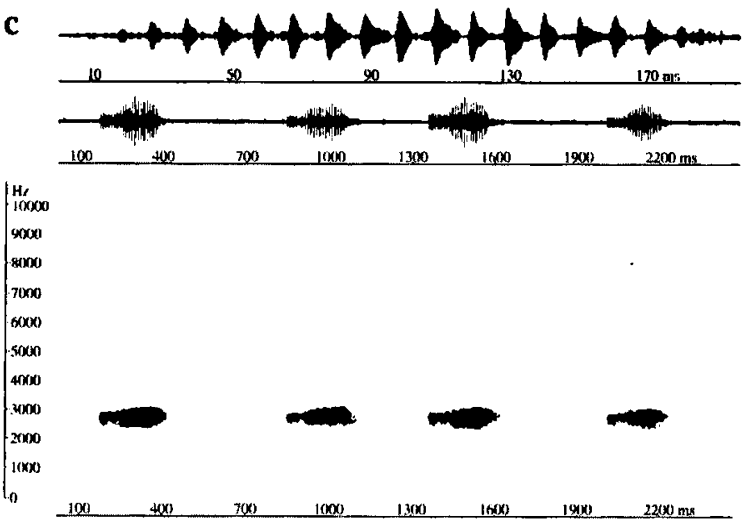

b

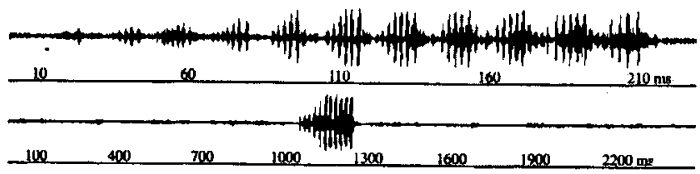

14
10000
9000
8000
7000
6000
5000
4000
-3000
2000
1000
0

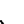
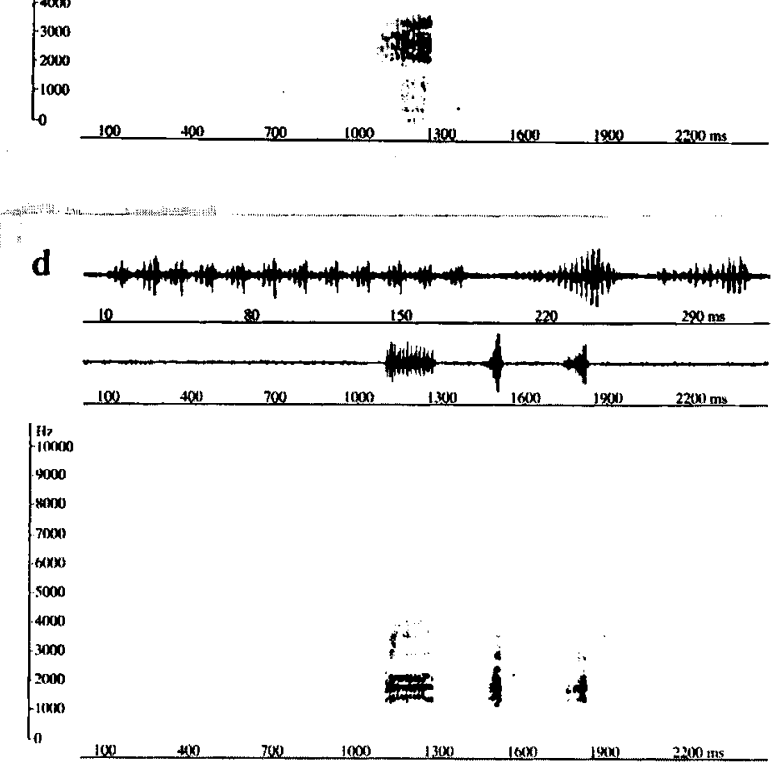

Fig. 2. From bottom to top: audiospectrogram and oscillogram of a 2.5 second recording of a characteristic mating call. Top: expanded oscillogram showing the temporal details of the notes; a, Scinax nasica; b, Scinax nebulosa, c, Scinax parkeri; d, Scinax rubra.

pulse rates ranging from 195 to 240 pulses/second, but Bolivian recordings showed pulse rates ranging from 53 to 57 pulses/second. The only parameter that shows slightly less dramatic differences between the calls described, is the dominant frequency: $3250 \mathrm{~Hz}$ according to Duellman (1978) and ranging from $3453 \mathrm{~Hz}$ to $3958 \mathrm{~Hz}$ in the present study. In spite of the differences in pulse rate and duration, the audiospectrograms provided (Fig. 1 in Duellman, 1970 and Fig. 3 in Duellman, 1972) show some structural similarities with our Fig. 1d, emphasising two wide, flat, frequency bands, the upper one raising in frequency at the beginning of the call.

Duellman \& Pyles (1983) provided numerical data on the calls of $S$. garbei (then Ololygon) from Santa Cecilia (Ecuador). Curiously enough, several of the variables are not even within the ranges of the previously published data for recordings obtained in the same site (Duellman, 1978). The discrepancies include the following parameters: note repetition rate ranging from 54.5 to 72.3 notes/minute in 1983 and reported to be 14 notes/minute in 1978; call duration, ranging from 370 to $650 \mathrm{~ms}$ in 1983 and from 160-260 $\mathrm{ms}$ in 1978; pulse rate, ranging from 80 to 100 pulses/second in 1983 and from 195 to 240 pulses/second in 1978; dominant frequency, ranging from 1564 to $1926 \mathrm{~Hz}$ in 1983 and estimated to be $3250 \mathrm{~Hz}$ in 1978 . In any event, our data on the mating calls from Bolivian $S$. garbei do not coincide with most of the numerical parameters reported for the mating calls of Ecuadorian frogs of this species, either as reported by Duellman (1970a, 1972, 1978) or as described later by Duellman \& Pyles (1983). 
Further research on this widespread and highly variable species could provide information about the actual taxonomic status of different populations.

\section{Scinax nasica (Cope, 1862)}

This is a medium-sized species (maximum SVL: $37.0 \mathrm{~mm}$ ) of uncertain phylogenetic relationships which has been considered a member of the $S$. rubra, $x$-signata, and staufferi groups (Duellman \& Wiens, 1992; De la Riva, 1993). It occurs throughout the same range as $S$. fuscovaria. Its mating system is explosive and breeding occurs in temporary ponds.

Recordings were obtained at Santa Cruz de la Sierra $\left(14^{\circ} 48^{\prime} \mathrm{S} 63^{\circ} 10^{\prime} \mathrm{W}\right)$ where males called after heavy rains from short grasses, in the middle of a pond, or on the ground near the shore. The mating call consisted of one pulsed note, of short duration, with low dominant and fundamental frequencies $(970 \mathrm{~Hz})$ and it was emitted in long call groups in rapid succession ( 337 calls per minute) at regular intervals (Fig. 2a). De la Riva (1993) described the vocalisations of this species recorded at the same time and locality. His description is based on the same recordings as ours.

\section{Scinax nebulosa (Spix, 1824)}

This is a relatively small species (maximum SVL: males $29.5 \mathrm{~mm}$, females $36.0 \mathrm{~mm}$ ) of the $S$. rostrata group (Duellman, 1972). It inhabits open areas in the lower Amazon Basin from the Guiana region to Mato Grosso (Brazil) and Bolivia.

Recordings were obtained at Puerto Almacén where the species had a prolonged breeding system, lasting during the whole rainy season and probably beyond it. Males called perched on riverine plants on river banks or near semi-permanent ponds. Calls were emitted by males spaced at long distance from each other. The advertisement call consisted of one note $(240 \mathrm{~ms})$ emitted sporadically, with a low number of pulses and high dominant frequency (2870 Hz) (Fig. 2b).

Duellman (1972) described the calls of Hyla egleri (a junior synonym according to Hoogmoed \& Gruber, 1983). He described a call composed of 4-7 notes, repeated at a rate of 39.5 notes/minute.
The note had a mean duration of $160 \mathrm{~ms}$, a pulse rate of 58 pulses/second and emphasised harmonics at 720 and $1050 \mathrm{~Hz}$. Whereas the pulse rate reported is similar to the values found by us (mean 55.6), the durations (our mean $240 \mathrm{~ms}$ ), and particularly the emphasised frequencies (2374-2867 $\mathrm{Hz}$ in the Bolivian recordings), are far from the values reported by Duellman (1972). However, the audiospectrogram provided (Duellman, 1972: 195, fig. 1) shows a call over $200 \mathrm{~ms}$ in duration and with emphasised frequencies from $2500 \mathrm{~Hz}$ to $5000 \mathrm{~Hz}$, showing a general structure very similar to our Fig. 2b.

Hödl (1977) described the calls of $H$. egleri from the area of Manaus (central Amazon, Brazil). He described a call composed of two types of notes: a primary note and a much shorter secondary note. We did not detect the existence of secondary notes in our recordings from Bolivia. Furthermore, neither the temporal nor the spectral values reported by Hödl (1977) agree with our recordings of Bolivian frogs.

Duellman \& Pyles (1983) provided numerical data on calls of $S$. nebulosa (then Ololygon egleri) from Belém de Pará (Brazil). The descriptive data for the call of $S$. nebulosa do not agree with the previously published description by the senior author (Duellman, 1972). According to that description $S$. nebulosa has only one note per call, with an average note repetition rate of 62.3 notes/ minute, an average duration of $130 \mathrm{~ms}$, an average pulse rate of 60 pulses/second, and dominant frequencies ranging from 3840 to $4147 \mathrm{~Hz}$. While the values for pulse rate are close to those found by us, the other values do not show similarities with our results.

In summary, the descriptions of the calls of $S$. nebulosa appear to be rather conflictive. However, the uniformity of the morphological characteristics of this species throughout its range (De la Riva, unpublished data) leads us to believe that the differences in call descriptions reported may be the result of differences in methods of analysis rather than actual taxonomic differences between populations.

Scinax parkeri (Gaige, 1929)

This extremely small species (maximum SVL: 23.3 


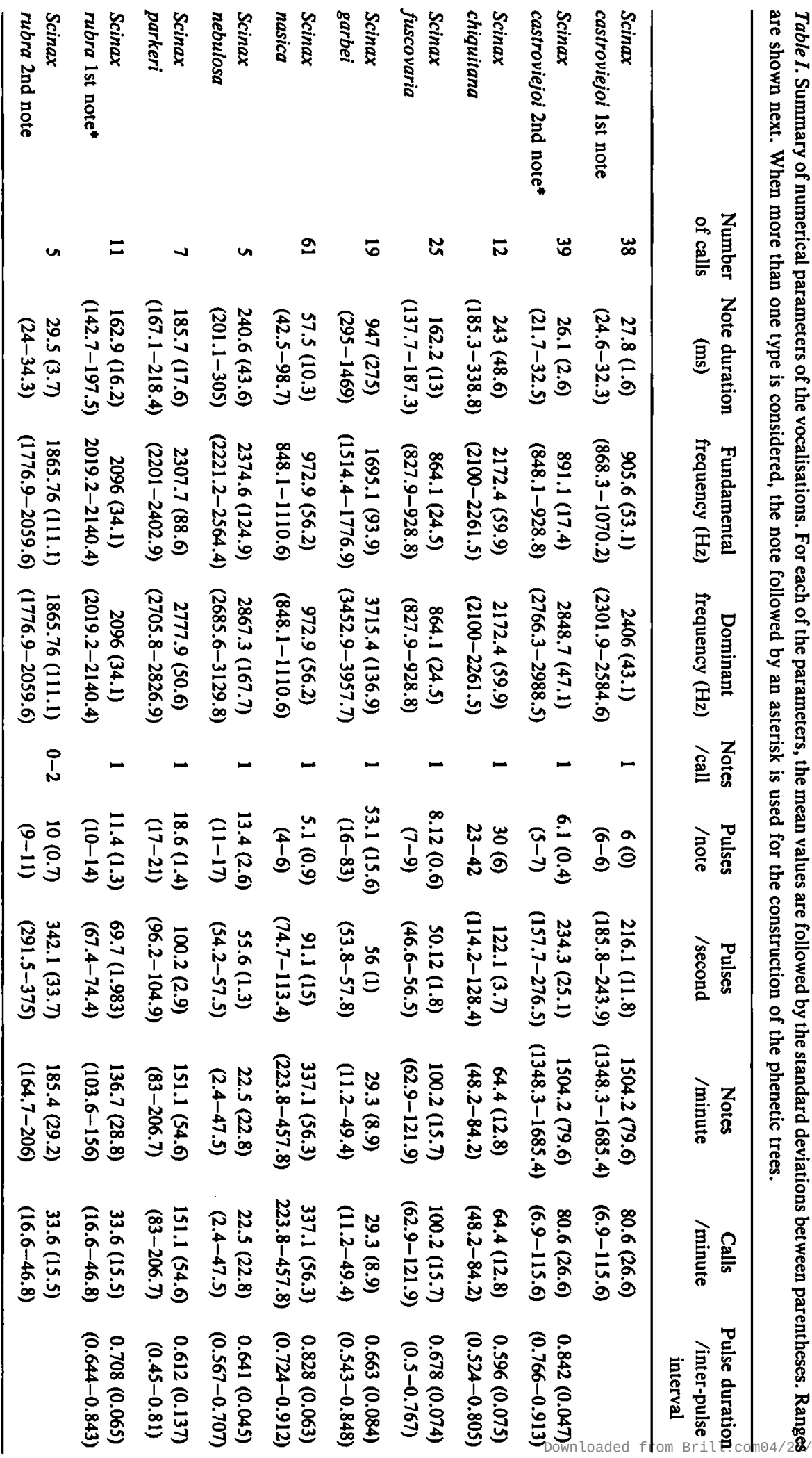


$\mathrm{mm})$ presumably is a member of the dubious $S$. staufferi group (Duellman \& Wiens, 1992). It was formerly considered by Lutz (1973) a junior synonym of $S$. fuscomarginata (Lutz, 1925) a position followed by several authors (Frost, 1985; De la Riva, 1990a) although Duellman \& Wiens (1992) considered $S$. parkeri as a valid species. It occurs at least in northern Bolivia and adjacent Brazil. It is characteristic of open habitats, and is probably a prolonged breeder during the whole rainy season.

Recordings were obtained at the type locality, Buenavista $\left(17^{\circ} 27^{\prime} \mathrm{S} 63^{\circ} 40^{\prime} \mathrm{W}\right)$, where males called perched on low grasses in a large flooded area. The call consisted of one short pulsed note $(186 \mathrm{~ms})$ with high dominant and fundamental frequencies (approximately 2300 and $2800 \mathrm{~Hz}$ ) (Fig. 2c). Calling activity was sporadic. To the best of our knowledge, no previous descriptions of the calls of Scinax parkeri have been published.

\section{Scinax rubra (Laurenti, 1768)}

This medium-sized species (maximum SVL: males $36.1 \mathrm{~mm}$, females $43.6 \mathrm{~mm}$ ) is widespread in the Neotropics from southern Panama throughout northern South America east of the Andes to central Bolivia, and southeastern Brazil. It is likely that a complex of species is currently being included under this name (Frost, 1985). The habitat of $S$. rubra includes both forests and open, disturbed areas.

Recordings were obtained at Puerto Almacén, where $S$. rubra is an explosive species breeding in temporal ponds. Males emitted their calls while perching on both leaves and branches of bushes and small trees. Males formed large choruses that often persisted until dawn. The call was emitted sporadically and consisted of two pulsed notes (Fig. 2d). The longer note (primary note) is often emitted in isolation and is longer in duration and higher in frequency than the second $(163 \mathrm{~ms}$ and $2100 \mathrm{~Hz}$, versus $29 \mathrm{~ms}$ and $1865 \mathrm{~Hz}$ in the second note). The second note can be repeated with a high number of pulses (342 pulses per second).

Rivero (1969) described the call of $S$. rubra (then Hyla rubra) from Estado Bolívar, Venezuela as a $200 \mathrm{~ms}$ long pulsed call with dominant frequency of about $1250 \mathrm{~Hz}$. He compared this call with that of
Hyla $x$-signata (Spix, 1824) and found them to be different. Both the audiospectrogram and the numerical data reported for $S$. rubra in Venezuela differ markedly from our recordings of Bolivian $S$. rubra. However, the structure of the call of $\boldsymbol{H}$. $\boldsymbol{x}$ signata from Estado Miranda, Venezuela (fig. 1 in Rivero, 1969) resembles our Fig. 2d, but it shows a slightly lower fundamental frequency. It would not be unlikely that Rivero considered $S$. $x$-signata what actually was $S$. rubra (and vice versa) since the taxonomy of both species is very complex.

Duellman (1970b) described the mating call of $S$. rubra (then Hyla rubra) from Santa Cecilia (Ecuador) as being a single short note (mean duration $130 \mathrm{~ms}$ ) with dominant frequency centered at 1581 $\mathrm{Hz}$ and an average pulse rate of 63 pulses/second. Campbell (1971) later described the mating call of Scinax rubra (then Hyla) from Panama as one pulsed note (pulse frequency 66-72 pulses/second) with a dominant frequency of $1600 \mathrm{~Hz}$ and a duration of 140-150 ms. Whereas the duration and pulse rate are somewhat comparable to the characteristics of the longer note described by us (duration range $142-197 \mathrm{~ms}$, pulse rate range $67-74$ pulses/ second), his description does not agree with our recordings because it does not report the existence of a secondary note. However, the fact that the dominant frequency of the call was located at 1600 $\mathrm{Hz}$ is not reflected at all in the audiospectrogram of the call (fig. 2 of Campbell, 1971). At any rate, the spectral characteristics of the call of the Panamanian frogs as depicted in this figure do resemble those found in our analyses. Campbell (1971) indicated that the call characteristics of his recordings were similar to those reported for this species in Ecuador by Duellman (1970b).

Duellman (1978) provided a description of the mating call of Scinax rubra (then Hyla) from Santa Cecilia (Ecuador) which coincided with that of the Panamanian calls of this species described by Campbell (1971). On the other hand, Schlüter (1979) described the call of Scinax rubra (then Hyla) from Peru as being composed of two different types of calls, a long ( $200 \mathrm{~ms})$ pulsed note and a shorter note (50 $\mathrm{ms}$ approximately). Similarly, our recordings from Bolivia show two note types as well, though with shorter durations (long 142-167 


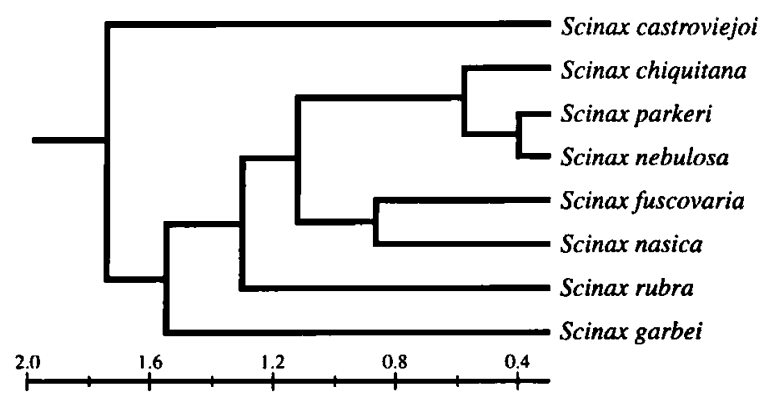

Fig. 3. Phenetic tree resulting from the UPGMA analyses of 12 numerical parameters of the calls of eight species of Scinax from Bolivia. The scale represents standard distances.

$\mathrm{ms}$, short 24-34 ms). The dominant frequencies of our recordings appear to be slightly lower for both notes than those shown by Schlüter (1979), however, the pulse rate of the longer note shown for the Peruvian frogs (estimated to be 60 pulses/second) is similar to that found by us (range 67-74 pulses/ second). The discrepancy in mating calls between the descriptions of the calls from Panama and Ecuador on the one hand, and from Peru and Bolivia on the other hand, suggests that the individuals recorded in these locations may belong to two different types or may have developed distinctly different dialects. A careful re-evaluation of the taxonomic status of $S$. rubra in these locations may be fruitful.

\section{Quantitative comparisons of the advertisement calls}

The UPGMA phenetic tree (Fig. 3) has a co-phenetic correlation coefficient of 0.897 , which indicates a solid level of consistency. On the other hand, the consistency between the tree and the currently accepted phylogenetic relationships within the genus Scinax (see Duellman \& Wiens, 1992) is not high, although the relationships among the species are not clear to taxonomists. The few established affinities are not well reflected by the phenogram. $S$. nebulosa and $S$. garbei are closely related (both belong to the rostrata group) but their calls are not grouped in the tree. On the other hand, $S$. parkeri is clearly different from the rest of the species, because of its small size, although it currently is included with $S$. nasica in the $S$. staufferi group,

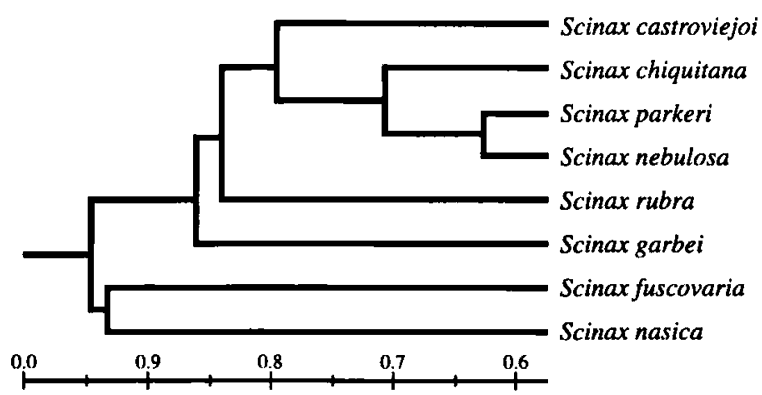

Fig. 4. Phenetic tree resulting from the audiospectrographic correlations of the primary notes of the calls of eight species of Scinax from Bolivia. The scale represents correlations.

whose monophyly is not demonstrated (Duellman $\&$ Wiens, 1992). The advertisement call of S. parkeri is similar to that of $S$. nebulosa, according to both Figs. 3 and 4.

The audiospectrographic correlation phenogram (Fig. 4) is rather consistent with the UPGMA phenetic tree, but does not show concordance with the tentative phylogeny of the genus. Again, S. castroviejoi is markedly separated, but not to the same degree as in Fig. 3. This species is grouped with $S$. chiquitana, and $S$. nebulosa and $S$. parkeri (the pair most closely clustered). These four species probably belong to four different species groups. Although in both Fig. 3 and Fig. 4, S. rubra and S. garbei, and $S$. fuscovaria and $S$. nasica, are clustered together, the relative positions of the pairs are not the same.

The two phenograms cluster the species in a similar way. The affinity between the trees resulting from the two methodologies is even more striking if we consider that the audiospectrographic correlation method does neither include any variables related to the rate of emission of the utterances nor to the number of different notes in a call (five out of twelve parameters included in the UPGMA). However, as we can see, there is no correlation between phylogeny and characteristics of the calls. The phenograms do not clearly reflect ecological relationships either. Most of the species considered are mainly open habitat dwellers. Scinax chiquitana lives in the forest, and $S$. garbei and $S$. rubra are euryoecious species found both in the open and in forest formations. These last two species are distantly associated in the phenograms, and the difference in habitat of $S$. chiquitana is not reflected in either of the phenograms. 
In summary, although according to some authors closely related species may show similarities in their calls (Schiøtz, 1973), the study of the genus Scinax does not conform to this trend and supports the results of Duellman (1970b) who did not find great coherence between the classification of the species of Hyla and the similarities among mating calls (but see Márquez et al., 1993). This lack of consistency may be a result of the fact that the intrageneric relationships of this group are far from being clearly established. On the other hand, the agreement between the two methods of analysis suggests that the holistic approach provided by the audiospectrographic correlation is a powerful technique for comparison of sounds. This new technique may eventually become a more objective and agile alternative to the labor-intensive technique of extraction of numerical variables for multivariate analysis.

\section{Acknowledgments}

We are indebted to the Museo de Historia Natural "Noel Kempff Mercado", of Santa Cruz de la Sierra, Bolivia, for its collaboration. Fieldwork in South America was supported by a grant from the Asociación de Amigos de Doñana to I. De la Riva. Edwin Chacón allowed us to record calls in his ranch, Puerto Almacén. We are particularly grateful to A. Machordom who performed the phenetic analyses of the calls through UPGMA and generated the phenetic trees from the audiospectrogram correlation matrix. Additional help for the analysis was provided by S. Reig. Sound analyses were funded by project CYCIT PB 89-0045C (PI: P. Alberch) Ministerio de Educación y Ciencia, Spain. C.W. Clark and R. Cocroft provided useful methodological advice for the analyses.

\section{References}

Barrio, A., 1965. El género Physalaemus en la Argentina. Physis, 25: 421-448.

Barrio, A., 1966. Divergencia acústica entre el canto nupcial de Leptodactylus ocellatus (Linné) y L. chaquensis Cei (Anura, Leptodactylidae). Physis, 26: 275-277.

Blair, W.F., 1955. Differentiation of mating call in spadefoots, genus Scaphiopus. Texas J. Sci., 7: 183-188.

Blair, W.F., 1958. Mating call in the speciation of anuran amphibians. Am. Nat., 92: 27-51.

Blair, W.F., 1959. Call differences as an isolation mechanism in southwestern toads. Texas J. Sci., 8: 87-106.

Campbell, H.W., 1971. Observations on two species of the Hyla rubra group in Panama (Anura, Hylidae). J. Herpetol., 5: 52-55.

Clark, C.W., P. Marler \& K. Beeman, 1987. Quantitative analysis of animal vocal phonology: an application to swamp sparrow song. Ethology, 76: 101-115.

Donnelly, M.A. \& C.W. Myers, 1991. Herpetological results of the 1990 Venezuelan expedition to the summit of Cerro Guaiquinima, with new Tepui reptiles. Amer. Mus. Novitates, 3017: 1-54.

Drewry, G.E. \& A. Stanley Rand, 1983. Characteristics of an acoustic community of Puerto Rican frogs of the genus Eleutherodactylus. Copeia, 1983: 941-953.

Duellman, W.E., 1970a. Identity of the South American hylid frog Garbeana garbei. Copeia, 1970: 534-538.

Duellman, W.E., 1970b. The hylid frogs of Middle America. Monogr. Mus. nat. Hist. Univ. Kansas, 1: 1-753.

Duellman, W.E., 1972. South American frogs of the Hyla rostrata group (Amphibia, Anura, Hylidae). Zool. Meded. Leiden, 47: 179-195.

Duellman, W.E., 1978. The biology of an equatorial herpetofauna in Amazonian Ecuador. Univ. Kansas Mus. nat. Hist. misc. Publ., 65: 1-352.

Duellman, W.E. \& R.A. Pyles, 1983. Acoustic resource partitioning in anuran communities. Copeia, 1983: 639-649.

Duellman, W.E. \& A.W. Salas, 1991. Annotated checklist of the amphibians and reptiles of Cuzco Amazonico, Peru. Univ. Kansas Mus. nat. Hist. occ. Pap., 143: 1-3.

Duellman, W.E. \& J.J. Wiens, 1992. The status of the hylid frog genus Ololygon and the recognition of Scinax Wagler, 1830. Univ. Kansas Mus. nat. Hist. occ. Pap., 151: 1-23.

Fouquette, M.J., Jr. \& A.J. Delahoussaye, 1977. Sperm morphology in the Hyla rubra group (Amphibia, Anura, Hylidae), and its bearing on generic status. J. Herpetol., 11(4): 387-396.

Frost, D.R. (ed.), 1985. Amphibian species of the world. A taxonomic and geographical reference: 1-732 (Allen Press Inc. \& ASC, Lawrence, Kansas).

Heyer, W.R., 1977. Taxonomic notes on frogs from the Madeira and Purus rivers, Brasil. Papéis avuls. Zool. S. Paulo, 31: 141-162.

Heyer, W.R., A. Stanley Rand, C.A. Goncalves da Cruz, O.L. Peixoto \& C.E. Nelson, 1990. Frogs of Boraceiá. Arq. Zool. S. Paulo, 31: 237-410.

Hödl, W., 1977. Call differences and calling site segregation in anuran species from central Amazonian floating meadows. Oecologia, 28: 351-363.

Hoogmoed, M.S. \& U. Gruber, 1983. Spix and Wagler type specimens of reptiles and amphibians in the natural history musea in Munich (Germany) and Leiden (The Netherlands). Spixiana, Suppl. 9: 319-415.

Jameson, D.L., 1955. Evolutionary trends in the courtship and mating behavior of Salientia. Syst. Zool., 14: 105-119.

Johnson, C., 1959. Genetic incompatibility in the call races of Hyla versicolor Le Conte in Texas. Copeia, 1959: 327-335.

Lutz, B., 1973. Brazilian species of Hyla: i-xviii, 1-260 (Univ. Texas Press, Austin). 
Márquez, R., I. De la Riva \& J. Bosch, 1993. Advertisement calls of Bolivian species of Hyla. Biotropica, 25(4).

Reynolds, R.P. \& M.S. Foster, 1992. Four new species of frogs and one new species of snake from the Chapare region of Bolivia, with notes on other species. Herpetological Monogr., 6: 83-104.

Riva, I. de la, 1990a. Lista preliminar de los anfibios de Bolivia con datos sobre su distribución. Boll. Mus. reg. Sci. nat. Torino, 8: 261-319.

Riva, I. de la, 1990b. Una especie nueva de Ololygon procedente de Bolivia (Anura: Hylidae). Revta. esp. Herpetol., 4: 81-86.

Riva, I. de la, 1992a. Comentarios sobre el género Gastrotheca (Anura Hylidae) en Bolivia y descripción de una nueva especie. Revta. esp. Herpetol., 6: 15-22.

Riva, I. de la, 1992b. A new species of Phrynopus from Bolivia (Anura: Leptodactylidae). Herpetologica, 48: 111-114.

Riva, I. de la, 1993. A new species of Scinax (Anura: Hylidae) from Argentina and Bolivia. J. Herpetol., 27(1): 41-46.

Rivero, J.A., 1969. Sobre la Hyla rubra Laurenti y la Hyla xsignata Spix (Amphibia, Salientia). Mems. Soc. Cienc. nat. La Salle, 29: 109-118.
Rohlf, F.J., 1992. NTSYS-pc: Numerical taxonomy system of programs, version 1.70. (Exeter Publishing Co., Setauket, New York).

Schiøtz, A., 1973. Evolution of anuran mating calls. Ecological aspects. In: J.L. Vial (ed.), Evolutionary biology of the anurans; contemporary research on major problems: 311-319 (Univ. Missouri Press, Columbia).

Schlüter, A., 1979. Bio-akustische Untersuchungen an Hyliden in einem begrenzten Gebiet des tropischen Regenwaldes von Peru. Salamandra, 15: 211-236.

Sneath, P.H.A. \& R.R. Sokal, 1973. Numerical taxonomy. The principles and practice of numerical classification: $\mathbf{i}-\mathbf{x v}$, 1-573 (W.H. Freeman, San Francisco).

Tosi, J.A., O. Unzueta, L.R. Holdridge \& A. Gonzales, 1975. Mapa ecológico de Bolivia (M.A.C.A., La Paz).

Zimmerman, B.L., 1983. A comparison of structural features of calls of open and forest habitat frog species in the Central Amazon. Herpetologica, 39: 235-246.

Received: 17 March 1993

Revised: 16 July 1993 